\section{Value Chain Management as Essentials of Pricing Strategy for Digital Marketing Companies}

\author{
E. L. Makarova, N. Todorovic
}

Elena L. Makarova, https://orcid.org/0000-0003-4100-4879, Southern Federal University, 105/42 Bolshaya Sadovaya St., Rostov-onDon 344006, Russia, elmakarova@sfedu.ru

Nikolina Todorovic, Promo Digital Media, 50 SW 10th St., Miami, Florida, 33130, USA, promodigitalgroup@gmail.com

\begin{abstract}
Introduction. Many businesses nowadays struggle to develop an effective pricing strategy that would boost their sales volume and improve profitability. Some of them may overcharge for their products and services, and usually chase customers away with their profit-hungry image. Others may undercharge as they either do not recognize the value they provide to a customer or simply deliver a below-the-standard project/service. Nevertheless, traditional pricing based mainly on the cost of production is a thing of the past as customers' needs and demands constantly change and what they would like may no longer be expensive to produce. As such, it is important to focus on psychological factors to understand the value customers are looking for and then amplify on those values when determining the right pricing strategy. Theoretical analysis. The theoretical management principles were determined as the patterns of subjects' behavior for the strategic management planning, value chain management, manufacturing and sale of products and services. The theory of managing a pricing strategy has proposed a number of tools to optimize the integrative framework for profit driven B2B pricing model, which allows developing a value chain management strategy for digital marketing agencies. Methodology. The basic statement of the problem determining strategic pricing methods for digital marketing agencies, depending of various factors is given. Results. During the research the authors explore several pricing strategies for digital marketing agencies and different online services they provide. The purpose of this article is to shift from traditional to strategic pricing methods for digital marketing services, which nowadays require flexibility, critical thinking, agency's role in the process understanding, the value they provide, and a total scope of work, including time and resources invested in the completion of a project.
\end{abstract}

Keywords: value chain management, pricing strategy, digital marketing, search engine optimization.

Received: 20.06.2020 / Accepted: 20.08.2020 / Published: 30.11.2020 This is an open access distributed under the terms of Creative Commons Attribution License (CC-BY 4.0)

DOI: https://doi.org/10.18500/1994-2540-2020-20-4-422-428

\section{Introduction}

Establishing an appropriate, yet effective pricing strategy is one of the challenges many entrepreneurs must face nowadays. Overpricing products or services may give away the impression

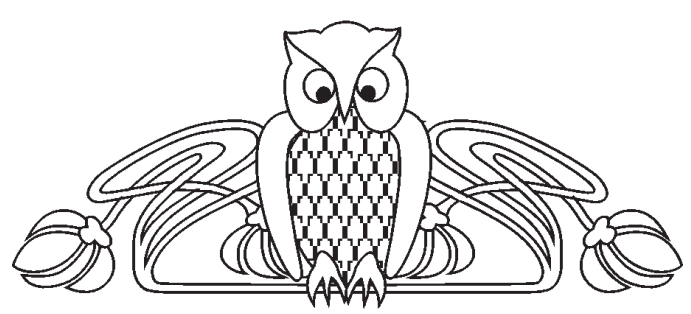

of a profit-hungry company - an image that turns away many customers and poorly affects client acquisition strategy overall. On the other hand, setting low prices in an intensely competitive market may point out to poor, below-the-standard quality of the product or service [1]. However, if the price strategy is developed and implemented correctly, it can and, in most cases, will increase both sales volume and profitability [2]. To be able to determine effective prices for any company's product or service, it is important to understand the business concept of strategic pricing. Strategic pricing is a model that encompasses proactive measures to create the conditions under which better and more-profitable pricing outcomes are the natural results. It is based on the idea of setting a price for a product/service based on its value to the customer or on competitive strategy rather than solely on the cost of production. The truth is people often make purchasing decision based more on psychological factors than on logical ones [3]. In other words, sometimes what customers appreciate and need in most cases is not necessarily most expensive to produce or deliver to them. With that being said, developing an effective pricing strategy starts in understanding what customers truly value; using such a lever to increase profitability and sales volume, especially in digital marketing industry where such value can be ambiguous and, hence, hard to recognize at times.

\section{Theoretical analysis}

The theoretical marketing principles determine the patterns of behavior for subjects of the system strategic management process of planning, manufacturing and sale for products and services. They are the basis for the effective implementation of industrial, commercial and economic activities. According to these principles, the following provisions should be taken into account:

a) the needs and desires of customers as well as the requirements of the external and the possibilities of the internal environment determine the characteristics of the production and sale for goods and services of the company;

b) the goal of the company is determined by its mission, taking the balance of society, organization and the environment interests into account; 
c) the effectiveness of the sale of goods and services depends on the correct determination of target markets, output volumes and timing of access to the market;

d) the necessity of constant improvement and update of the product line and services' assortment;

e) the coherence of the marketing strategy and tactics determine the flexibility and timeliness of the organization's response to changes in demand, as well as the possibility of forming and stimulating the needs of consumers [4, p. 31].

Determining an effective pricing strategy is usually a challenging decision-making process due to the volatility of costs and ever-changing market itself.
Many strategists would agree that pricing decisions are acutely significant and hard to make because price changes may cause deviations directly associated with various objectives such as customer retention, profit, sales, and market share. Marketing scholars underscore the prominence of treating price as a strategic variable in the marketing mix $[5,6]$. As shown on Fig. 1, these strategic management variables (e.g., pricing strategy) is correlated to other variables such as external market influence (e.g., economic value, perceived quality, competitor response), internal firm influence variables (e.g., costs, margins, cost structure), and goal variables (e.g. profit, sales and market share, and customer retention).

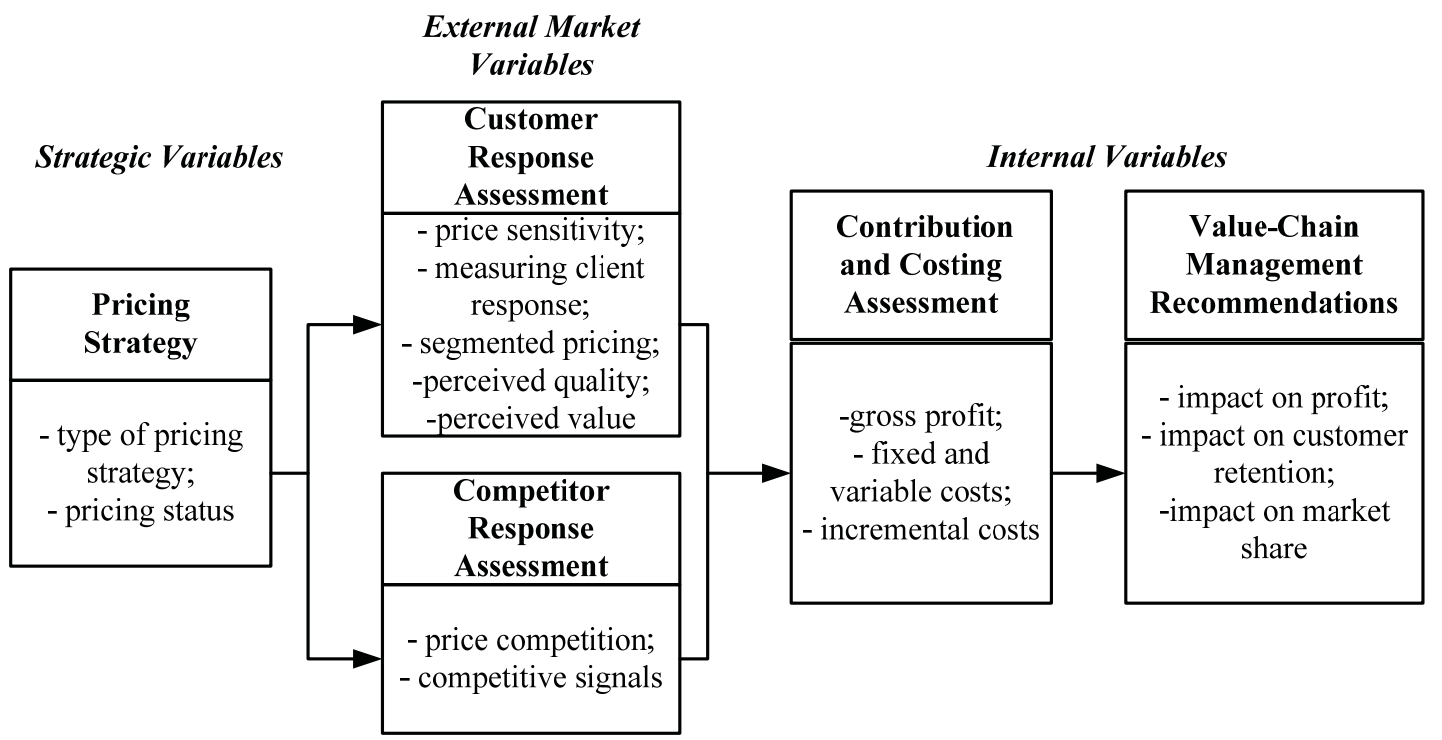

Fig. 1. Integrative framework for profit-driven B2B pricing strategy

Due to the relationship between the variables, any deterioration of prices can impact perceived quality, competitor's response, economic value and other types of variables already mentioned. Figure 2 demonstrates a hypothetical example of how dif- ferent customers may experience different levels of sensitivity to different prices. Four different levels of sensitivity are depicted for four different customers, who each represent a price-utility segment. The utility - customer's preference for the product/service -

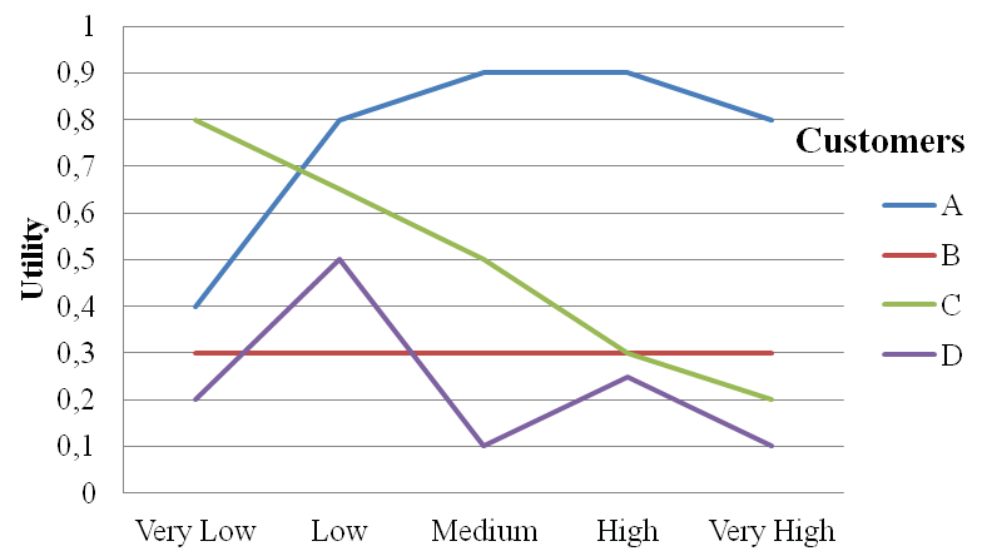

Fig. 2. A graph of the client sensitivity in the price range (color online) 
for customer B shows to be insensitive to any price fluctuations. For customer C, raising the price would lower the utility. Customer A prefers to steer clear of both cheap and expensive products/services, and would rather choose medium-priced product/service designs. Lastly, customer D indicates a strong sensitivity relationship to any price changes.

Pricing strategy is an organization's plan to set and manage prices to compete in a market and achieve organization goals and objectives (see Porter, 1980; Walker \& Ruekert, 1987 for additional relevant definitions of strategy). Pricing implementation is specific action and behavior that enacts

Evidently, the top management should establish pricing goals, objectives, and strategies that will be consistent with marketing and corporate goals, objectives, and strategies [7]. Undeniably, pricing decisions have vital influence on reaching organizational success, especially when they are tactical and short-term based. For instance, increasing prices may lead to the increase in unit margins and short-term profits. Increased prices may also signal quality, prestige, or create exclusivity [8]. Decreasing prices may stimulate short-term sales volume [9, p. 21]. Lowering prices may also work in one's favor when dealing with the competition [10]. Evidently, the significance of achieving an appropriate strategic pricing decision is highlighted by these competing forces which only further demonstrate how vexing and contentious organizational pricing decisions can be.

Pricing strategy is an organization's plan to determine and control its prices to compete in a market and achieve organization goals and objectives [11]. The magnitude to which pricing strategy has an influence on organizational interest, perception, and interpretation is the first challenge [12, p. 76]. In other words, pricing strategy must initially be present and acknowledged in an organization. According to Mintzberg, such strategy must be "made in advance of the actions to which [it applies], and [it is] developed consciously and purposefully" [13, p. 11]. Mintzberg also asserts that such strategy must continually be adapted to reflect the ever-changing external business environment. According to Nagle and Holden (1994), pricing strategy development and implementation is characterized by the processes of strategic analysis and strategy formulation. Normatively speaking, a pricing strategy plan needs to be long-term based, forward-looking, and goal driven. In addition, a pricing strategy planning process should be emphasized on classes of transactions for types of market segments, consumers, products, or services rather than an individual pricing transaction or event [14, p. 429]. However, for an efficient and effective plan to take place, its mere creation is not enough. Planning pricing strategy must be properly managed and adjusted following its creation and must grow to be an important part of organizational attention and cognition with its presence - a part that reflect organizational strategic agenda to achieve success.

\section{Methodology}

Digital communications development prospects are developing in unity with the development of marketing management theory, which, as is always known for the appearance of new promotion channels and instruments in digital environment. Marketing communications specialists record the main trends and methods in their development and adapt its practice of planning and implementing communication campaigns. Trends are a spiral of certain areas of marketing practice using interactive advertising that will have a decisive influence on consumer behavior in the near future [15, p. 84].

Several digital features were distinguished for marketing management methodology.

1. Decentralization of the information provider includes ownership of the choice, since what exactly to buy is determined in a personal dialogue with the buyer.

2. Digital media have multimedia ability to transfer content, including text, numbers, information, pictures, graphics, video and photo materials, including visual and verbal, tactile, olfactory elements of communication.

3 . The nature of the transmission of information has fundamentally changed due to the interactive nature of the digital media "from vertical to horizontal".

4. Classical media, inform an indefinite circle of people, have exclusively mass character of work with the audience. New digital media have a targeted and interactive nature. It is personified and capable of transmitting multimedia messages and involve feedback from the target audience.

At its core, personalization is a process of understanding real intentions, desires and needs for the person, as well as the transfer of relevant, targeted and significant experience for this person. In practical terms, this does not mean, firstly, the construction and use of a client model that describes his needs (what the client buys), his values (what the client is looking for in the product) and motivation (when the client buys and what lends itself to incentives), and secondly, management of customer experience (management of customer experiences in all his contacts with the company at points of contact throughout the client's life cycle) [16, p. 16].

5. Digital media, unlike traditional ones, update their information (content) constantly, around the clock, access to them is instant. 
6. The transfer of information using digital media, unlike classical media, involves technical and information technologies and methods, including the necessary professional competencies of employees [17, p. 29].

The choice of digital tools is determined based on the goals and objectives of the company, its size, the specifics of a particular type of activity, the composition and characteristics of business processes, the stage of development of the life cycle. For small businesses, the main goals are such as brand promotion, attracting new customers, increasing sales. For medium-sized companies, the main goals are to retain customers, increase repeat sales without significant costs, and maintain contact with customers. For large businesses, the main goals are: reducing maintenance costs and maintaining a high level of customer loyalty [18, p. 24].

Determining strategic pricing methods for digital marketing agencies depends on numerous factors and, as such, can be quite challenging. Most of the digital marketing agencies follow a simple pricing formula: $\cos t+$ markup $=$ price. In other words, most of them charge their customers the amount that they need to pay to deliver the service (e.g. software costs, template designs, etc.) plus the amount of money they wish to earn. Now, the markup aspect of pricing generally corresponds to the amount of value an agency delivers in the deal. By definition, markup is the difference between a product's selling price and cost as a percentage of the cost. Calculating Markup Percentage for digital marketing agencies formula is presented below:

$$
\text { Markup } \%=\frac{\text { Selling Price }- \text { Cost }}{\text { Cost }} \times 100 \% \text {. }
$$

For example, if a digital marketing service is offered for $\$ 400$ and costs $\$ 100$, the additional price increase is $(\$ 400-100) / \$ 100 \times 100 \%=30 \%$.

Generally, agency chooses to charge a $20-50 \%$ range markup on all digital marketing services, and these variables are usually very easy to modify. However, the aspect of cost is much more challenging to tweak. If an agency decides to charge hourly for a project or service that will usually be the cost plugged into the equation. On the other hand, if an agency charges weekly, monthly, or quarterly, for example, the cost will be determined based on the total amount of time and resources that will go into work for a specific project or service lifetime. Since many factors determine the pricing strategy, various calculations can become a complex decision-making process for each service offered. Let's take a look at how to strategically set a price for different digital marketing services.

\section{Results}

Price Website Design Services. Website design and development is a complex process with many variables, which can make creating a value chain management strategy slightly complicated. For this service, there are three factors to consider: UI, UX, and graphic design. UI design is mainly based on color scheme, logo placement, layout, typeface, etc. UX design is a part of UI, but it requires more skills and efforts to ensure the full functionality and user-friendliness of a website. Lastly, graphic design encompasses the process of creating content and assets for the website, e.g. banners, images, videos, etc. It is important to know and understand these three processes within the website design service to determine an appropriate pricing strategy. Generally, a digital marketing agency should charge either hourly rate or value-based flat fee for the website design, with some upfront fees included on top of that. These fees would cover the costs of web hosting (e.g. WordPress, Wix, etc.) and domain registration. In addition to the initial design work, the website will need ongoing maintenance. Usually, website maintenance is relatively simple when trying to stay current with new trends and designs. As such, it is generally not a part of a recurring monthly cost for long-term clients. However, if the maintenance includes more code-based, backend work that requires continual optimization for speed, bugs and glitch removals, and other non-aesthetic components of web maintenance, a flat monthly fee should be charged. When creating a pricing strategy for web services, a digital marketing agency should keep in mind the number of specialists necessary to accomplish all these tasks and determine their price markup accordingly.

Price Pay-Per-Click (PPC) Services. Payper-click (PPC) services are another value chain management strategy that includes strategizing, setting up, managing, and reporting on campaigns set up through Google AdWords, Facebook, Instagram, Bing, and other ad platforms. This service requires mapping out and researching the efficient keywords, choosing the right target audience for an ad, designing eye-catching content, etc. Generally, the pricing formula for PPC is based on determining spending versus earning. In other words, digital marketing agencies usually charge the price that is based on how much it is costing them to launch a campaign plus their markup price for the launching, maintaining, optimizing, and analytical reporting on the ad. Some of these digital marketing agencies choose to, in fact, charge hourly for PPC projects. The reason why this is not recommended is that a PPC manager may choose to work slower to acquire more profit. To resolve this problem, it is a great idea to start 
charging a flat rate or a monthly retainer for PPC services. On top of that, if a digital marketing agency has a client that spends over $\$ 2,000$ a month on ad budget, they should charge that client a flat fee $+a$ percentage of the ad spend (10-25\%).

Price Social Media Services. Every so often, digital marketers underprice social media service as they are not aware of how much value they bring to their clients. Social media marketing is, in fact, a powerful tool for creating brand awareness and leveraging that awareness to boost sales. As such, value chain management agency need to better understand the scope of their social media work as well as an estimate of their cost + the desired profit margin to be able to determine the pricing strategy correctly. The first thing an agency should consider is the role of content manager, which includes the analysis of online audiences and the development and execution of social media strategy that will target such niche audience. Furthermore, an agency needs to take a role of a community manager as well to handle all of audience interactions on day-to-day-basis, respond to inquiries, comments, etc. Also, it is important to monitor trends and conversations across social media platforms to be able to stay on top of trending discussions, updates, hashtags, or anything else relevant to the online growth strategy of a business. When understanding these roles, a digital marketing agency evaluates the amount of work necessary to be put in to execute the strategies and sets the price accordingly. Generally, agencies should charge 20-50\% markups along with any software costs they acquire along the way. It is also a possibility to charge a flat fee anywhere between $\$ 400$ and $\$ 600$ a month for social media marketing and management, given that any pay-per-click services related to social media platform would either be charged separately if the workload is high, or included in the markup price as a part of existing social media pricing package if there is no high and constant demand for ads. Lastly, while some clients need a simple page setup, some may need additional services such as setting up a Business Manager account or creating high-end images and promotional videos. In such case, an additional fee should be charged per hour per additional work.

Price E-mail Marketing Services. E-mail marketing is another service that digital marketing agencies tend to undercharge. E-mail marketing is an instrumental marketing service that allows companies to share their messages and promotional materials with a wide audience simultaneously. Regardless of how it is used, as a branding tool or a sales funnel, e-mail marketing can grow a business is conducted correctly. This service includes several processes such as creating the automation map and segmentation management to ensure that a high-quality content is targeted at the right audience. The key to setting an effective value chain management strategy for e-mail marketing service is knowing the costs that come with delivering it as well as the value provided to the customer. Digital marketing agencies should follow the general pricing formula, where the price will be a result of the costs acquired in addition to markup price. A flat rate pricing would be recommended in this scenario and should be based on the average hours necessary to complete an e-mail marketing campaign from start to finish. To determine the cost of this flat fee, digital marketing agencies should simply multiply the overall number of hours invested in the completion of a project by the entire working force (e.g. copywriter, designer, etc.) with the corresponding hourly rate. Lastly, markup of $20-50 \%$ should be added to this cost to determine the final charging price for e-mail marketing services.

Price Search Engine Optimization (SEO) Services. Search engine optimization, also known as SEO, is a digital marketing service that, simply put, improves online visibility of a website on search engines such as Google, Bing, Yahoo Gemini, and others. Such service comprises three types: local SEO (aimed at local business searches), on-page SEO (includes website content, images, keywords, URLs, linking strategy, and user experience), and off-page SEO (composed of links to that lead to a specific website from external sources). SEO is a long process with a lot of nuances, thus setting the pricing strategy can be quite challenging at times. Digital marketing agencies should be to evaluate the amount of time it will take to complete an SEO project, which is very difficult given the fact that SEO is an ongoing service which never truly ends. As such, the costs for SEO projects will add to digital marketing agency's monthly recurring revenue. Nevertheless, agencies should consult with their SEO specialists on a pricing table for these projects as they can give them a better idea of what the project entails and how much workload it will require. When determining the strategic price for SEO service, it is important to include all the software costs that are necessary to deliver the results and add 20-50\% markup to those costs to get an idea of a final charging price for the client. It is strongly recommended to charge SEO services hourly, as the nature of search engine optimization is volatile and there may be more work in demand for some businesses than others. Due to its unpredictability, it is wiser to charge hourly rather flat fee rates because the latter may financially poorly affect a digital marketing agency, or even so client themselves. 
Developing a value chain management strategy for any business may be a tricky process - one that may cost them clients or help acquire new ones if done correctly. The main reasons for the increase in the costs of digital marketing include: the rapid growth of the mobile Internet audience; growth in the number of Internet users; decrease in the effectiveness of traditional advertising in a number of activity areas; large selection of target audiences for targeting increasing the amount of time spent online; the possibility of using automated instruments of purchasing advertising; integration with other advertising tools; dynamic targeting, remarketing opportunities; example of competing companies; the relative cheapness of interactive advertising; more accurate measurement of the effectiveness of digital advertising; the cost of traditional advertising $[19$, p. 300]. This is particularly the case with businesses that offer online services, such as digital marketing agencies, where the question of value may vary from client to client. Being able to understand what customers value is a precious asset that can help guide a pricing table effectively, ultimately driving more sales and boosting profitability of an agency. Digital marketers need to be able to evaluate the amount of time, work, and resources different services or projects entail, and base their pricing strategy around that data. Generally, the pricing formula usually includes acquired costs (for paying employees or freelancers, software systems, design tools, etc.) plus markup which an agency wished to earn for a given project. Needless to say, it should always be one's goal to earn more than they spend, ending up far from the breakeven point as much as possible within reason. This, of course, does not mean overcharging, but rather amplifying on the value they can deliver to a client and the ability to satisfy their needs. Whether charging hourly or flat rate, determining the right pricing strategy for digital marketing services can essentially make or break an agency, so it is crucial to confidently calculate all of the variables and always keep in mind the value of work provided.

\section{References}

1. McFarlane B. Pricing Strategy: How to Price a Product. Create Space Independent Publishing Platform, 2012. $52 \mathrm{p}$.

2. Smith T. J. Pricing Strategy: Setting Price Levels, Managing Price Discounts \& Establishing Price Structures. Mason, South-Western Cengage Learning, 2012. 344 p.

3. Schindler R. M. Pricing Strategies: A Marketing Approach. Sage Publication, 2012. $416 \mathrm{p}$.

4. Podoprigora M. G., Makarova E. L. Marketing: osnovy, zakonomernosti, perspektivy razvitiya [Marketing: the basics, patterns, development prospects: Atraining manual]. Taganrog, Izd-vo Yuzhnogo federal'nogo universiteta, 2016. 86 p. (in Russian).

5. Dolan R. J., Simon H. Power Pricing: How Managing Price Transforms the Bottom Line. New York, Free Press, 1997. $384 \mathrm{p}$.

6. Beneke J., Flynn R., Dreig T., Mukaiawa M. The Influence of Perceived Product Quality, Relative Price and Risk on Customer Value and Willingness to Buy: A Study of Private Label Merchandise. Journal of Product \& Brand Management, 2013, vol. 22, no. 3, pp. 218-228. DOI: https://doi.org/10.1108/jpbm-02-2013-0262

7. McMahon-Beattie U. The Strategy and Tactics of Pricing: A Guide to Profitable Decision Making by Thomas T. Nagel and Reed K. Holden. Journal of Revenue \& Pricing Management, 2002, no. 1, pp. 286-287. DOI: https://doi.org/10.1057/palgrave.rpm.5170032

8. Nagel T. T. Economic Foundations for Pricing. The Journal of Business. 1984, vol. 57, no. 1, The University of Chicago Press, pp. 3-26.

9. Stephenson P. R., Cron W. L., Frazier G. L. Delegating Pricing Authority to the Sales Force: The Effects on Sales and Profit Performance. Journal of Marketing, 1979, vol. 43, no. 2, pp. 21-28. DOI: https://doi. org $/ 10.1177 / 002224297904300203$

10. Oxenfeldt A. R. A Decision-Making Structure for Price Decisions. Journal of Marketing, 1973, no. 37, pp. 48-53. DOI: https://doi.org/10.1177/002224297303700107

11. Ruekert R. W., Walker O. C. Interactions between Marketing and R\&D Departments in Implementing Different Business Strategies. Strategic Management Journal, 1987, vol. 8, iss. 3, pp. 233-248. DOI: https:// doi.org/10.1002/smj.4250080303

12. Dutton J. E., Jackson S. E. Categorizing Strategic Issues: Links to Organizational Action. Academy of Management Review, 1987, vol. 12, no. 1, pp. 76-90. DOI: https://doi. org/10.5465/amr.1987.4306483

13. Mintzberg H. The Strategy Concept I: Five Ps for Strategy. California Management Review, 1987, vol. 30, no. 1, pp. 11-24. DOI: https://doi.org/10.2307/41165263

14. Smith G. E., Woodside A. G. Chapter 9 Pricing theory and practice in managing business-to-business brands. In: Glynn M. S., Woodside A. G. (eds.). Business-ToBusiness Brand Management: Theory, Research and Executivecase Study Exercises (Advances in Business Marketing and Purchasing. Vol. 15). Emerald Group Publishing Limited, Bingley, 2009, pp. 429-486. DOI: https://doi.org/10.1108/S1069-0964(2009)0000015013

15. Shevchenko D. A. The Market of Digital Communications in Russia: The Situation and the Main Trends. Sistemnye tekhnologii [System technologies], 2018, no. 1 (26), pp. 84-88 (in Russian).

16. Godin V. V., Terekhova A. E. Digital advertising as a tool to promote goods or services. Project implementation experience. E-Management, 2019, vol. 2, no. 3, pp. 13-21 (in Russian). DOI: https://doi.org/10.26425/2658-34452019-3-13-21

17. Shevchenko D. A. Digital marketing: an overview of channels and tools. Prakticheskiy marketing [Digital marketing], 2019, no.10 (272), pp. 29-37 (in Russian). 
18. Krylov A. N., Kuzina G. P., Golyshkova I. N., Yazintsev R. A. Improving the efficiency of business communications bazed on the use of digital channels. Vestnik universiteta, 2019, no. 6, pp. 19-26 (in Russian). DOI: https://doi.org/10.26425/1816-4277-2019-6-19-26
19. Mordovin A. V., Polusmakova N. S. Digital advertising in cross-channel communications. Proceedings of the Voronezh State University of Engineering Technologies, 2017, vol. 79, no. 4, pp. 297-305 (in Russian). DOI: https:// doi.org/10.20914/2310-1202-2017-4-297-305

\section{Cite this article as:}

Makarova E. L., Todorovic N. Value Chain Management as Essentials of Pricing Strategy for Digital Marketing Companies. Izv. Saratov Univ. (N. S.), Ser. Economics. Management. Law, 2020, vol. 20, iss. 4, pp. 422-428. DOI: https://doi.org/ 10.18500/1994-2540-2020-20-4-422-428

\section{УДК 338.24}

\section{Формирование и управление цепочками создания ценности как основа ценовой стратегии цифровых маркетинговых компаний}

\section{Е. Л. Макарова, Н. Тодорович}

Макарова Елена Львовна, кандидат педагогических наук, доцент кафедры менеджмента и инновационных технологий, Южный федеральный университет, Ростов-на-Дону, elmakarova@ sfedu.ru

Тодорович Николина, генеральный директор, Promo Digital Media, Майами, Флорида, США, promodigitalgroup@gmail.com

Введение. Многие компании в настоящее время пытаются разработать эффективную стратегию ценообразования, которая позволит повысить объем продаж и увеличить прибыль. Некоторые из них могут завышать цену на свои продукты и услуги и, как правило, тем самым отталкивают таким имиджем потенциальных клиентов в своем стремлении к получению прибыли. Другие могут занижать цену, поскольку либо не признают ценности товара/услуги, которые они предоставляют клиенту, либо это товар/услуга, не отвечающие стандарту. Тем не менее, традиционное ценообразование, основанное, главным образом, на себестоимости продукции, осталось в прошлом, поскольку потребности и требования клиентов постоянно меняются, и то, что они хотели бы получить, может не быть дорогим в производстве. Таким образом, важно сосредоточиться на психологических факторах, чтобы понять, какую ценность ищут клиенты, а затем усилить эти ценности при определении пра- вильной ценовой стратегии. Теоретический анализ. В качестве теоретических принципов управления были определены модели поведения субъектов для стратегического планирования, управления цепочками создания ценности, производства и продажи продуктов и услуг. Теория управления стратегией ценообразования предлагает ряд инструментов для оптимизации интегративной структуры модели ценообразования В2В, ориентированной на прибыль, что позволяет разработать стратегию управления цепочкой создания стоимости для агентств цифрового маркетинга. Методология. В методологическом отношении дается основная постановка задачи, определяющая методы стратегического ценообразования для агентств цифрового маркетинга в зависимости от различных факторов. Результаты. В ходе исследования авторы изучили несколько стратегий ценообразования для агентств цифрового маркетинга и различных онлайн-услуг, которые они предоставляют клиентам. Целью данной статьи является рассмотрение перехода от традиционных методов стратегического ценообразования к услугам цифрового маркетинга, которые в настоящее время требуют гибкости, критического мышления, понимания роли агентства в процессе, ценности, которые они предоставляют, а также общего объема работы, включая время и ресурсы, вложенные в завершение проекта.

Ключевые слова: управление цепочками создания ценности, стратегия ценообразования, цифровой маркетинг, поисковая оптимизация.

Поступила в редакцию: 20.06.202 / Принята: 20.08.2020 / Опубликована: 30.11 .2020

Статья опубликована на условиях лицензии Creative Commons Attribution License (CC-BY 4.0)

\section{Образец для цитирования:}

Makarova E. L., Todorovic N. Value Chain Management as Essentials of Pricing Strategy for Digital Marketing Companies [Макарова Е. Л., Тодорович Н. Формирование и управление цепочками создания ценности как основа ценовой стратегии цифровых маркетинговых компаний] // Изв. Сарат. ун-та. Нов. сер. Сер. Экономика. Управление. Право. 2020. Т. 20, вып. 4. C. 422-428. DOI: https://doi.org/10.18500/1994-2540-2020-20-4-422-428 